\title{
Genetic Variability among Maize Inbreed Lines under Moisture Stress Condition
}

\author{
Devraj Lenka ${ }^{1}$, Bibhu P. Singh ${ }^{1}$, Devidutta Lenka ${ }^{1}$ and Swapan K. Tripathy ${ }^{2 *}$ \\ ${ }^{I}$ Department of Plant Breeding and Genetics, College of Agriculture, \\ OUAT, Bhubaneswar, India \\ ${ }^{2}$ Department of Agricultural Biotechnology, College of Agriculture, \\ OUAT, Bhubaneswar, India \\ *Corresponding author
}

\section{A B S T R A C T}

\begin{tabular}{|l|}
\hline K e y w o r d s \\
Genetic variability, \\
Inbreed lines, \\
Drought tolerance, \\
Maize \\
(Zea mays L.) \\
\hline Article Info \\
\hline $\begin{array}{l}\text { Accepted: } \\
17 \text { November } 2019 \\
\text { Available Online: } \\
10 \text { December } 2019\end{array}$ \\
\hline
\end{tabular}

Drought is considered to be one of the major abiotic stress factors that severely limit grain yield production, often causing extensive economic loss to agriculture. Improving drought tolerance in maize has become one of the top priorities in maize breeding programs. Identification of maize germplasm with superior drought tolerance is a prerequisite for such purpose. Out of a set of 35 inbred lines, nine inbred lines viz., UMARKOTE-3, CML-411, CML-122, CML-40, CML-27, CML-336, CML-191, CLO-2450 and CAL-1415 showed high tolerance to drought. Such inbred lines were able to maintain shorter anthesis-silking interval (ASI), higher shelling \%, moisture\%, cob length, cob diameter, 100 grain weight and comparatively higher grain yield when subjected to drought stress. In contrast, CML-161 and CML-300 showed exactly opposite trend as compared to those tolerant ones and these two recorded lowest grain yield among the inbred lines under water stress. The potential use of promising inbred lines that are able to alleviate the negative impacts of drought on growth and development, are underway for production of maize hybrids.

\section{Introduction}

Maize (Zea mays L.) has pivotal role in cereal production next to rice and wheat. It is very sensitive to excess or deficit soil moisture. About $67 \%$ of the total maize production in the developing world comes from low \& low middle income countries. The global demand for maize is estimated to increase from $526 \mathrm{M}$ tons to $784 \mathrm{M}$ tons from 1993 to 2020 , with most of the increased demand coming from developing countries (Rosegrant et al., 2009). By 2050, the demand for maize in developing world will be double. Therefore, there is dare 
need for much more effort for maize production in the changing climatic conditions, particularly relating to water stress, salinity and extreme temperature. Among these, moisture stress seems to be a major constraint in maize productivity under rain fed condition (Hall et al., 1981). Drought affects maize at any stage of its life cycle. But, maximum damage is inflicted when it occurs during flowering. Deficit moisture leads to delayed silking and female sterility caused by embryo abortion (Moss and Downey, 1971) resulting significant reduction in grain yield. The annual estimated yield loss due to drought may be around 24 million tonnes which is equivalent to $17 \%$ of a normal year's production in a developing world. Therefore, an attempt was undertaken to study genetic variability among a set of 35 inbreed lines under drought stress.

\section{Materials and Methods}

A set of 35 maize inbreeds were evaluated at EB-II section of the Department of Plant Breeding and Genetics, College of Agriculture, OUAT, Bhubaneswar in field condition during Rabi 2018-19. The experiment was laid out in a randomized block design (RBD) with two replications. Each entry was represented by 2 lines of 4 meters row length having $60 \mathrm{~cm}$ spacing between rows and $20 \mathrm{~cm}$ between plant to plant within a line after thinning. Fertilizers were applied at the rate of $120 \mathrm{~kg} \mathrm{~N}, 60 \mathrm{~kg} \mathrm{P}_{2} \mathrm{O}_{5}$ and $60 \mathrm{~kg}$ $\mathrm{K}_{2} \mathrm{O}$ per hectare in the form of Urea, SSP and MOP respectively along with FYM 12 cart loads/ha and Zinc Sulphate $25 \mathrm{~kg} / \mathrm{ha}$. Normal agronomic practices and plant protection measures were applied to raise a normal crop. Drought stress was imposed by with-holding irrigation before 10 days of flowering and stopped for about one month and the irrigation was resumed when soil moisture reached permanent wilting point at a depth of 40-60 $\mathrm{cm}$. Plant height $(\mathrm{PH})$, ear height $(\mathrm{EH})$, anthesis-silking interval(ASI), cob length(CL), cob diameter(CD), Shelling percentage(SP), kernel rows per $\operatorname{cob}(\mathrm{KR} / \mathrm{C})$, kernels/row(K/R), total number of grains/plant(TG/P) and GY/P were recorded on five randomly selected competitive plants per replication per inbred line. The mean of five plants were computed for statistical analysis. The characters like days to $50 \%$ anthesis (DA), days to $50 \%$ silking(DS), days to $75 \%$ dry husk(DH), moisture percentage(MP)and grain yield/ $\mathrm{ha}(\mathrm{GY} / \mathrm{Ha})$ were calculated on plot basis. Anthesis-silking interval was calculated by counting the days between date of silking and anthesis.

\section{Results and Discussion}

The mean performance of 35 maize inbreeds in respect of 16 different quantitative characters is presented in Table 1 . The overall mean was 70.34 days with a range of 69.00(CML-469) to 72.50days (CML-161). The genotypes viz.CML-411, CML-116, CML-118, CML-114, CML-295, CML-59, CML-336, CML-468, CML-300, CML-194, CML-470, CML-414, CML-359, CML 469, CLO-2450, CAL-1415 and BML-07 were considered as early type for $50 \%$ anthesis. Days to $50 \%$ silking varied from 69.00 (CAL1415) to74.50 days (CML-161) with an overall mean of 71.89 days. The genotypes viz. CML-59, CML-191, CML-194, CAL1415 were considered early for $50 \%$ silking. Anthesis-silking interval (ASI) varied from 3.50 (CML-468) to 0.00 (CML-451) with overall mean of 1.56 days. In the present investigation, the genotypes viz. JSPL-I, CML-59, CML-453, CML-487, CML-191, CML-194, CAL-1415, and CML-451 revealed occurrence of anthesis and silking on the same day (zero ASI value). Days to $75 \%$ dry husk varies from 97.50 days in (CML-161) to 103.50 days(UMARKOTE-3) with an overall mean of 100.54 days and the inbreeds except Umarkote-3,JSPL-I,CML-468,V-334 and 
BML-6 all are having early maturity duration. The magnitude of plant height ranged from 97.42cm (CML-161) to $185.10 \mathrm{~cm}$ (CML-113) with an average of $136.36 \mathrm{~cm}$. Among the inbreds, Umarkote-3, CML-116, CML-118, CML-114, CML-470 and CML-451 are showing lesser plant height and significantly different from others which is desirable in any plant breeding programme. The magnitude of ear height ranged from $33.70 \mathrm{~cm}$ (CML-431) to $78.90 \mathrm{~cm}$ (CML-469) with an average of $51.64 \mathrm{~cm}$. Among the inbreeds, CML-323, Umarkote-3, CML-118, CML-431, CML-295, CML-161, CML-300 and CML-412 showed lesser ear height which seems to be a desirable ideotype in normal breeding programme.

The range of shelling percentage among the maize inbreeds varied from $51.35 \%$ (CML412 ) to $83.70 \%$ (CML-359) with an average of $73.42 \%$. All the 35 inbreds evaluated were significantly different from CML-431, CML295, CML-412 and have higher shelling \% resulted in higher grain weight per cob, ultimately gave higher production. The range of moisture percentage ranged between 15.15(CML-161) to 22.55(Umarkote-3) with an average of 20.50 .

Among the inbreds, CML-411 and CAL-1415 showing higher level of moisture $\%$ positively correlated with high yield. The magnitude of cob length ranged from $10.50 \mathrm{~cm}$ (CML-300)to $22.33 \mathrm{~cm}$ (CML-40) with an average of 16.23 $\mathrm{cm}$. Among the inbreeds, Umarkote-3, CML411, CML-122, CML-40,CML-59, CML-27, CML-336, CML-191, CML-414, CML-469, CLO-2450 and CAL-1415 have higher ear length and therefore, produce higher number of seeds and ultimately leads to more production. The variation in cob girth ranged from $8.44 \mathrm{~cm}$ (CML-300) to $19.87 \mathrm{~cm}$ (CAL1415 ) with a mean value of $14.22 \mathrm{~cm}$. CML411, CML-122, CML-40, CML-59, CML-27, CML-191, CML-414, CLO-2450, and CAL1415 revealed higher ear girth which resulted in more number of rows per ear and ultimately contributes to higher production. Number of kernel rows per ear ranged between 9.75(CML-300) to 19.01(CML-40) with an overall mean of 14.65 and the genotypes Umarkote-3, CML-411, CML-122, CML-40, CML-59, CML-27, CML-414, CLO-2450, CAL-1415 showed higher value ultimately contributes to higher production. The range of number of kernels/row among the inbreds varied from 12.12 (CML-300) to 30.70 (CML-411) with an overall mean of 22.14.

Inbreeds like Umarkote-3, CML-411, CML122, CML-40, CML-27, CML-336, CML-191, CLO-2450, and CAL-1415 resulted higher number of kernel/ row. The variation in 100kernel weight ranged from 16.45g (CML-161) to 32.28g (CML-336). Umarkote-3, CML-411, CML-122, CML-40, CML-27, CML-336, CML-191, CLO-2450 and CAL-1415 have shown more 100 grain-weight. Grain yield per plant of 35 different inbreeds ranged between 6.36g (CML-300) to 58.28g (CML-40) with an average of 38.23 gram. Among the inbreeds, Umarkote-3, CML-411, CML-122, CML-40, CML-27, CML-336, CML191, CLO-2450 and CAL-1415 resulted higher grain yield/plant.

The variation in grain yield per hectare of above 35 inbred maize ranged between 3.85(CML-300) to 36.81(CAL-1415) with an average of 24.26 quintals per hectare. These inbreeds also turned out to have promising performance based on grain yield/ha and hence, such top yielding inbreeds evaluated under acute drought stress may have merit in drought tolerance breeding for maize hybrid development.

The estimates of parameters of genetic variability such as, coefficient of variation (PCV and GCV), heritability $\left(\mathrm{h}_{\mathrm{bs}}^{2}\right)$ and expected genetic advance from selection have been presented below in Figure 1. 
Table.1 Mean performance of 35 maize in breeds for different agro -economic traits

\begin{tabular}{|c|c|c|c|c|c|c|c|c|c|c|c|c|c|c|c|c|c|}
\hline SL. & Genotype & DA & DS & ASI & DH & PH & $\mathbf{E H}$ & SP & MP & CL & CD & $\mathrm{KR} / \mathrm{C}$ & $\mathbf{K} / \mathbf{R}$ & TG/P & GW & GY/P & GY/Ha \\
\hline 1 & CML323 & 71.00 & 72.50 & 1.50 & 102.00 & 129.00 & 34.68 & 81.20 & 20.35 & 15.96 & 14.27 & 16.80 & 29.20 & 305.50 & 20.90 & 50.05 & 30.82 \\
\hline 2 & UMARKOTE-3 & 70.00 & 72.00 & 2.00 & 103.50 & 109.76 & 38.86 & 75.05 & 22.55 & 21.17 & 16.60 & 17.70 & 27.80 & 336.40 & 20.93 & 41.24 & 25.35 \\
\hline 3 & CML -411 & 69.50 & 70.50 & 1.00 & 100.50 & 160.24 & 68.16 & 83.25 & 22.25 & 20.22 & 17.71 & 17.50 & 30.70 & 358.80 & 30.13 & 52.10 & 33.65 \\
\hline 4 & CML -116 & 69.50 & 70.50 & 1.00 & 99.00 & 104.52 & 66.48 & 72.25 & 19.90 & 12.12 & 13.95 & 16.30 & 13.50 & 145.30 & 28.22 & 35.88 & 21.34 \\
\hline 5 & CML -118 & 70.00 & 71.00 & 1.00 & 101.00 & 108.98 & 33.76 & 80.20 & 20.35 & 18.00 & 15.20 & 15.00 & 24.75 & 315.00 & 24.87 & 38.02 & 26.17 \\
\hline 6 & CML -122 & 71.00 & 72.00 & 1.00 & 102.50 & 145.94 & 66.17 & 82.45 & 17.50 & 20.99 & 18.06 & 17.10 & 29.80 & 294.75 & 27.15 & 53.28 & 33.38 \\
\hline 7 & JSPL-I & 71.00 & 71.00 & 0.00 & 102.50 & 144.40 & 45.68 & 77.60 & 18.45 & 17.12 & 13.74 & 16.85 & 25.90 & 231.00 & 26.17 & 47.14 & 28.43 \\
\hline 8 & CML -40 & 71.00 & 72.00 & 1.00 & 101.50 & 154.81 & 59.08 & 82.05 & 20.90 & 22.33 & 18.31 & 19.01 & 28.10 & 311.10 & 30.03 & 58.28 & 34.58 \\
\hline 9 & CM-324 & 70.50 & 71.50 & 1.00 & 101.50 & 121.06 & 56.92 & 79.45 & 21.10 & 16.49 & 13.20 & 13.60 & 17.60 & 173.40 & 22.58 & 45.50 & 28.51 \\
\hline 10 & CML - 431 & 70.50 & 73.50 & 3.00 & 100.00 & 122.10 & 33.70 & 57.50 & 21.30 & 11.73 & 8.94 & 10.80 & 12.20 & 108.40 & 21.69 & 23.95 & 14.54 \\
\hline 11 & CML -114 & 69.50 & 72.50 & 3.00 & 100.00 & 101.08 & 38.00 & 78.75 & 21.05 & 11.09 & 9.97 & 11.90 & 14.00 & 116.80 & 19.94 & 26.62 & 16.98 \\
\hline 12 & CML -295 & 69.50 & 72.50 & 3.00 & 100.00 & 116.83 & 37.27 & 52.55 & 21.45 & 12.26 & 9.94 & 10.14 & 13.40 & 118.90 & 22.12 & 19.05 & 11.76 \\
\hline 13 & CML -51 & 70.50 & 72.50 & 2.00 & 98.50 & 124.72 & 42.14 & 60.05 & 20.25 & 12.72 & 10.23 & 12.00 & 17.90 & 138.05 & 21.94 & 25.96 & 16.71 \\
\hline 14 & CML -59 & 70.00 & 70.00 & 0.00 & 99.00 & 168.08 & 60.48 & 79.90 & 20.40 & 19.77 & 17.85 & 17.00 & 25.95 & 242.50 & 31.93 & 56.65 & 34.40 \\
\hline 15 & CML-453 & 71.00 & 71.00 & 0.00 & 99.50 & 145.22 & 48.40 & 71.50 & 20.85 & 16.57 & 16.47 & 16.80 & 22.70 & 257.50 & 27.33 & 41.69 & 28.64 \\
\hline 16 & CML -27 & 70.50 & 71.50 & 1.00 & 100.00 & 145.98 & 57.92 & 78.95 & 17.30 & 21.27 & 17.90 & 17.02 & 28.60 & 235.80 & 28.12 & 52.58 & 33.90 \\
\hline 17 & CML -487 & 71.00 & 71.00 & 0.00 & 101.50 & 169.76 & 63.65 & 79.20 & 20.65 & 14.00 & 12.35 & 11.70 & 21.70 & 185.40 & 22.27 & 36.72 & 23.67 \\
\hline 18 & CML -336 & 70.00 & 72.00 & 2.00 & 101.50 & 144.40 & 65.28 & 79.15 & 20.85 & 19.17 & 18.20 & 16.40 & 28.35 & 325.70 & 32.28 & 54.01 & 34.60 \\
\hline 19 & CML-161 & 72.50 & 74.50 & 2.00 & 97.50 & 97.42 & 37.00 & 69.00 & 15.15 & 12.40 & 8.88 & 10.8 & 12.85 & 103.70 & 16.45 & 17.11 & 10.36 \\
\hline 20 & CML -191 & 70.50 & 70.50 & 0.00 & 101.50 & 154.88 & 56.26 & 80.80 & 19.20 & 19.71 & 18.44 & 16.62 & 27.15 & 252.8 & 31.74 & 54.01 & 34.96 \\
\hline 21 & CML -468 & 70.00 & 73.50 & 3.50 & 103.00 & 150.84 & 58.02 & 65.20 & 21.05 & 15.96 & 11.20 & 12.00 & 15.80 & 162.40 & 22.35 & 32.28 & 19.91 \\
\hline 22 & V -334 & 71.00 & 74.00 & 3.00 & 103.00 & 126.60 & 49.26 & 69.45 & 20.85 & 14.24 & 13.15 & 13.00 & 25.20 & 132.00 & 19.30 & 28.57 & 17.36 \\
\hline 23 & CML -300 & 70.00 & 73.00 & 3.00 & 100.50 & 110.48 & 34.42 & 73.40 & 21.05 & 10.50 & 8.44 & 9.75 & 12.12 & 106.55 & 19.33 & 6.36 & 3.85 \\
\hline 24 & CML -113 & 71.50 & 73.00 & 1.50 & 101.50 & 185.10 & 70.34 & 69.95 & 20.55 & 15.90 & 12.20 & 13.20 & 21.70 & 129.40 & 20.91 & 29.03 & 17.55 \\
\hline 25 & CML -412 & 71.00 & 72.00 & 1.00 & 101.00 & 123.84 & 34.66 & 51.35 & 21.35 & 16.76 & 13.24 & 13.80 & 18.40 & 221.75 & 24.43 & 29.76 & 19.27 \\
\hline 26 & CML -194 & 70.00 & 70.00 & 0.00 & 100.00 & 137.62 & 59.62 & 79.80 & 18.85 & 14.39 & 14.55 & 16.40 & 23.40 & 279.60 & 21.89 & 48.08 & 29.52 \\
\hline 27 & CML -470 & 70.00 & 73.00 & 3.00 & 98.50 & 99.59 & 42.30 & 73.90 & 21.15 & 12.47 & 10.90 & 11.13 & 13.80 & 117.60 & 19.91 & 20.85 & 12.60 \\
\hline 28 & CML -414 & 70.00 & 72.00 & 2.00 & 100.50 & 145.34 & 51.16 & 80.25 & 22.25 & 18.53 & 18.19 & 17.38 & 26.15 & 315.00 & 30.56 & 45.56 & 30.39 \\
\hline 29 & BML -06 & 71.50 & 74.00 & 2.50 & 103.00 & 161.81 & 67.43 & 82.35 & 21.30 & 16.08 & 15.60 & 16.80 & 24.85 & 317.85 & 22.15 & 43.63 & 29.96 \\
\hline 30 & CML -359 & 69.00 & 72.00 & 3.00 & 100.00 & 129.68 & 39.88 & 83.70 & 20.70 & 12.49 & 13.95 & 13.20 & 28.60 & 252.20 & 27.69 & 34.24 & 22.80 \\
\hline 31 & CML -469 & 69.00 & 71.00 & 2.00 & 99.00 & 178.72 & 78.90 & 79.10 & 21.30 & 17.33 & 17.27 & 16.80 & 23.60 & 285.40 & 24.10 & 46.92 & 27.87 \\
\hline 32 & CLO -2450 & 70.00 & 71.00 & 1.50 & 99.00 & 148.50 & 65.66 & 69.90 & 21.55 & 20.17 & 17.31 & 17.68 & 25.55 & 274.70 & 27.14 & 45.19 & 29.17 \\
\hline 33 & CAL -1415 & 69.00 & 69.00 & 0.00 & 98.00 & 177.52 & 73.58 & 77.20 & 21.00 & 20.76 & 19.87 & 18.65 & 28.80 & 312.75 & 31.40 & 53.54 & 36.81 \\
\hline 34 & BML -07 & 70.00 & 73.00 & 3.00 & 99.00 & 121.38 & 37.76 & 55.70 & 21.45 & 11.12 & 10.00 & 10.48 & 14.25 & 122.55 & 20.63 & 1819 & 11.39 \\
\hline \multirow[t]{3}{*}{35} & CML -451 & 71.00 & 71.00 & 0.00 & 100.00 & 106.24 & 34.52 & 57.70 & 21.45 & 16.13 & 11.30 & 11.60 & 20.50 & 187.80 & 25.60 & 25.90 & 17.81 \\
\hline & GM & 70.34 & 71.89 & 1.56 & 100.54 & 136.36 & 51.64 & 73.42 & 20.50 & 16.23 & 14.22 & 14.65 & 22.14 & 222.13 & 24.69 & 38.23 & 24.26 \\
\hline & CVe & 0.57 & 0.63 & 28.05 & 0.54 & 1.51 & 1.81 & 2.25 & 4.72 & 2.97 & 7.71 & 8.61 & 8.73 & 8.68 & 5.22 & 7.92 & 6.44 \\
\hline
\end{tabular}


Fig.1 Graphical representation of PCV, GCV, heritability and genetic advance for 16 traits

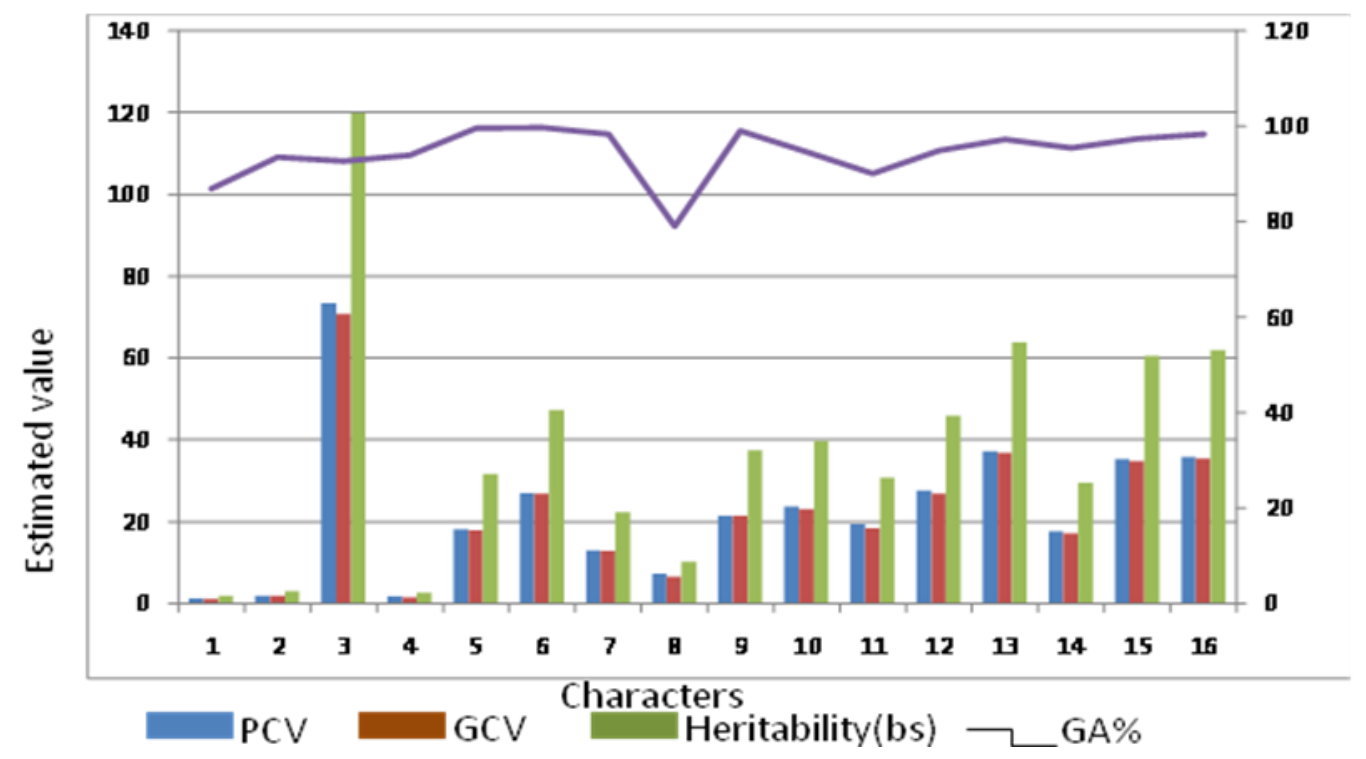

The present investigation revealed wide genetic variation among 35 inbreeds which might be due to their diverse base populations. Similar findings were reported by Ahmad et al., (2016), Mostafavi et al., (2013) and Homayoun (2011). Majority of traits showed smaller difference between PCV and GCV indicating little influence of the environment as also revealed by Ghosh et al., (2014).

Therefore, selection based on phenotypic values for most of the characters is expected to be effective. But low values of GCV for days to $50 \%$ anthesis (1.04), days to $50 \%$ silking (1.70), days to $75 \%$ dry husk (1.49), and moisture \% (6.48) indicated limited scope for improvement of these traits as also reported by Bawa et al., (2012), Hepziba et al., (2013) and Ghosh et al., (2014). However, other traits were by and large influenced by environmental factors leading to comparatively wider difference between PCV and GCV. Therefore, simple selections based on phenotypic variation may not be worthwhile for improving these traits. In the present study, high heritability was reported in days to $50 \%$ silking, anthesis silking interval, days to $75 \%$ dry husk, plant height, ear height, shelling\%, cob length, cob diameter, kernel rows/cob, no. of kernels/row, total grain/plant, 100 grain weight, grain yield/plant, grain yield/ha. Similar results have been obtained by Ghimire and Timsina (2015). Besides, Wattoo et al., (2013) also reported higher values of heritability for days to silking, days to tasseling and grain yield/ha.

Moderate to high heritability with moderate to low genetic advance were found in case of 100 kernel weights, number of kernel /row, grain yield/ plant, ear girth, number of kernel/row, number of kernel rows/ ear, number of kernels/row, and 100-kernel weight indicating non additive gene action for these traits (Dai $e t$ al., 1990 and Golbashy et al., 2010). In contrast, high heritability and with high genetic advance was realized in case of ear height, plant height, cob length, shelling $\%$ and grain yield $(\mathrm{q} / \mathrm{ha})$ suggesting predominant role of additive gene action in their inheritance and higher expected genetic gain through selection. 


\section{References}

Ahmad M, Saleem M, Ahsan M and Ahmad A. 2016. Genetic analysis of waterdeficit response traits in maize. Genet. Mol. Res, 15.

Bawa A, Addai IK and Kugbe JX. 2012. Evaluation of some genotypes of maize (Zea mays L) for tolerance to drought in Northern Ghana Maydica, a journal devoted to maize and allied species, 60. (2).

Dai, JY, Gu WL, Shen XY, Zheng B, Qi H and Cai SF 1990.Effect of drought on the development and yield of maize at different growth stages: Journal of Shenyang Agricultural University, 21(3): 181-185

Ghimire B and Timsina. 2015.Analysis of Yield \& Yield Attributing traits of maize germplasm in Chitwan, Nepal, Scrutiny International Research Journal of Agriculture, Plant Biotechnology and Bio Products (SIRJ-APBBP), 2 (4).

Ghosh A, Subba V, Roy A, Ghosh, A and Kundagrami S. 2014. Genetic Variability and Character Association of Grain Yield Components in Some Inbred Lines of Maize (Zea mays L.). Journal of Agroecology and Natural Resource Management (JANRM), 1 : 34-39.

Golbashy M, Ebrahimi M, Khorasani Sa, Khayatnezhad M and Gholamin Roza. 2010. The effect of drought stress on leaf chlorophyll content and stress resistance in maize cultivars (Zea mays) African Journal of Microbiology Research, 6(12): 2844-2848.

Hall A.J, Vilella F, Trapani N and Chimenti C. 1981. The effects of water stress and genotype on the dynamics of pollenshedding and silking in maize. Field Crops Research, 5: 349-363.

Hepziba SJ, Geetha K and Ibrahim SM. 2013. Research Note Evaluation of genetic diversity, variability, character association and path analysis in diverse inbreds of maize (Zea mays L.) Electronic Journal of Plant Breeding, 4(1): 1067-1072.

Homayoun H. 2011.Study of some morphological traits of corn hybrids. American-Eurasian Journal of Agricultural \& Environmental Sciences, 10(5): 810-813.

Moss GI and Downey LA. 1971. Influence of Drought Stress on Female Gametophyte Development in Corn (Zea mays L.) and Subsequent Grain Yield 1. Crop Science, 11(3).368-372.

Rosegrant M.W, Ringler C and Zhu T. 2009. Water for agriculture: maintaining food security under growing scarcity. Annual review of Environment and resources, 34:205-222.

Wattoo FM, Saleem M, Ahsan M and Basra Shahzad MA. 2013. Genetics of Physio- Agronomic Traits in Maize under Water Deficit Conditions, Pakistan Journal of Nutrition, 12 (4): 398-40.

\section{How to cite this article:}

Devraj Lenka, Bibhu P. Singh, Devidutta Lenka and Swapan K. Tripathy. 2019. Genetic Variability among Maize Inbreed Lines under Moisture Stress Condition. Int.J.Curr.Microbiol.App.Sci. 8(12): 2213-2218. doi: https://doi.org/10.20546/ijcmas.2019.812.263 